\title{
Synthesis, Characterization and Drug-Likeness Predictions of 1,3-Thiazole and Benzothiazole Derivatives
}

\author{
ARSHI NAQVI', \\ 'Department of Chemistry, College of Science, Taibah University, Al Madina Al Munawwara, \\ Kingdom of Saudi Arabia. \\ ${ }^{2}$ Biodiscovery-Solutions for future, Plot No 29, FF2, $2^{\text {nd }}$ street, Pearl Astragal Apartment, \\ Perumbakkam of Medavakkam, Solinganallur Main Road, Chennai, Tamil Nadu-600100, India. \\ ${ }^{*}$ Corresponding author E-mail: arshi_84@yahoo.com \\ http://dx.doi.org/10.13005/ojc/340660
}

Received: October 16, 2018; Accepted: November 26, 2018)

ABSTRACT

Heterocyclic compounds bearing nitrogen and sulphur in the main skeleton are reported to be a bioactive group. Thiazole and benzothiazole moieties are biologically significant class of this group. This research focus on the synthesis and characterization of 1,3-thiazole and benzothiazole derivatives. Drug likeness predictions were also undertaken for these newly synthesized compounds.

Keywords: Thiazole, benzothiazole, Synthesis, Drug likeness.

\section{INTRODUCTION}

Heterocycles delineate by far to be the utmost important class of organic chemistry. Both natural and synthetic heterocyclic molecules have been immensely explored for their profound applicability in the field of medicinal, industrial and agricultural chemistry. A wide array of biological activity affiliated with heterocyclic compounds has allured interest in the research of drug discovery ${ }^{1}$. As noticed from literature, family of nitrogen and sulphur heterocycles of both natural as well as synthetic origin is endowed with vast spectrum of biological activities and a gigantic amount of them have been formulated to the clinics globally ${ }^{2}$. This is the reason why the synthesis of heterocycles is of continuing interest to chemists. Nitrogen and Sulphur containing heterocyclic drug candidates have been reported to have biological activities like anti-bacterial ${ }^{3}$ anti-funga ${ }^{4}$, anti-oxidant ${ }^{5}$, anti-cancer ${ }^{6}$, anti-viral ${ }^{7}$, anti-convulsant ${ }^{8}$, anti-tubercular ${ }^{9}$, anti-HIV ${ }^{10}$ etc.

Thiazole, or 1, 3-thiazole, is a heterocyclic molecule bearing both sulfur and nitrogen heteroatoms. The most notable component of the vitamin thiamine (B1) and penicillin is the thiazole ring. The versatility of thiazole nucleus is manifested by the feature that construct various bioactive drugs like antimicrobial (sulfazole), antifungal (abafungin), antiretroviral (ritonavir), antineoplastic

This is an Open Access article licensed under a Creative Commons license: Attribution 4.0 International (CC- BY). Published by Oriental Scientific Publishing Company @ 2018

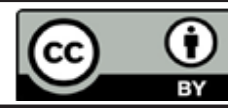


(Tiazofurin) ${ }^{11}$. Thiazole hybrids have been reported in possession of many pharmacological properties and are widely involved in biochemical processes. Cefdinir is a semi-synthetic cephalosporin (third generation) which exhibits magnificent activity against Staphylococcus species ${ }^{12}$. Norvir (HIV-1 protease inhibitor) constitutes of two non-identical substituted thiazole rings ${ }^{13}$. Thiazole/2-amino thiazole moiety bearing compounds are reported for the treatment of hypertension ${ }^{14}$, allergies ${ }^{15}$, hypnotics ${ }^{16}$, pain ${ }^{17}$, inflammation ${ }^{18}$, thrombosis ${ }^{19}$, tumour $^{20}$, inflammation ${ }^{21}$, etc. Thiazoles have also been reported to be a contributor in the flavor of brewed coffee ${ }^{22}$.

Benzothiazole is an elite bicyclic ring system. Benzothiazole skeleton embraces to be an attractive heterocyclic class which is known for its exciting medicinal traits. 2-substitued benzothiazole has unfold its usage as a vital structure in various therapeutics sectors ${ }^{23}$. The dopamine D2-agonist pramipexole (Mirapex), used for treating Parkinson's disease and restless legs syndrome is comprised of a fused bicyclic tetrahydrobenzothiazole motif ${ }^{24}$. Numerous amounts of biological activity are associated with this nucleus namely anti-microbial ${ }^{25}$, anti-leshmanial| $^{26}$, anti-helmintic ${ }^{27}$, anti-HIV ${ }^{28}$, antiinflammatory ${ }^{29}$, anti-cancer ${ }^{30}$, anti-convulsant ${ }^{31}$ etc.

Drug likeness is a qualitative criterion used for drug like property of the compounds. Different structural and molecular properties like hydrophobicity, hydrogen bond characteristics, molecule size etc. are evaluated in order to determine whether the predicted compound is similar to the known drugs or not. Generally, Lipinski's rule of 5 (RO5) is used to determine the drug likeness of the evaluated drug candidate ${ }^{32-33}$.

Since immense portion of biological potentials are associated with the family accommodating nitrogen and sulphur heteroatoms in the skeleton, it was worthy to synthesize and characterize some of its derivatives viz. 1,3-thiazoles and benzothiazoles and to explore their drug likeness estimations.

\section{MATERIALS AND METHODS}

The chemicals were purchased from Sigma-Aldrich/Merck. Melting points WERE determined in open capillary tubes and were uncorrected. Silica-gel-coated Al plates (Merck \& Co.) were used to check the purity of the compound. The structure of the compounds was elucidated by Infra-red (IR, recorded using KBr pellets on PerkinElmer Spectrum-BX-I Infrared Spectrophotometer) and ${ }^{1} \mathrm{H}-\mathrm{NMR}$ (recorded in Dimethyl sulphoxide (DMSO) on Jeol-300MHz instrument). Microanalysis of the compounds gave satisfactory results. All the synthesized compounds were assessed for their drug likeness properties by web-based software.

Synthesis of 4-Phenyl-1,3-thiazol-2-amine (1): Thiourea (2mol) and acetophenone (1 mol) were placed in round bottom flask, bromine $(0.95 \mathrm{~mol})$ was gradually added to this mixture. After addition of bromine the reaction mixture was heated on steam bath for 12 hours. The contents were diluted with water, heated until most of the solid had gone into the solution. The liquid was filtered under suction, cooled and the filtrate was alkalized with strong ammonium hydroxide. The precipitate was filtered and recrystallized from ethyl alcohol as colorless needles. Yield: $69.35 \%$; m.p: $149^{\circ} \mathrm{C}$; IR( $\left.\mathrm{KBr}\right)\left(\mathrm{cm}^{-1}\right)$ : 710, 780, 905, 1445, 1603, 1627-1685, 3210, 3431; ${ }^{1} \mathrm{H}-\mathrm{NMR}\left(300 \mathrm{MHz}\right.$, DMSO- ${ }_{\mathrm{d} 6}$ ): $\delta=2.50$ (DMSO), 3.9 (d, $\left.-\mathrm{NH}_{2}\right), 7.22-7.30(\mathrm{~m}, \mathrm{Ar}-\mathrm{H})$, 7.38-7.44 (m, Ar-H), 7.49 (s, thiazole-H5). Anal. Calc. for $\mathrm{C}_{9} \mathrm{H}_{8} \mathrm{~N}_{2} \mathrm{~S}: \mathrm{C} 61.34$, H 4.58, N 15.90; Found: C 61.38, H 4.60, N 15.85.

Synthesis of 2-chloro-N-(4-phenyl-1, 3-thiazol-2-yl)acetamide (2): Chloroacetyl chloride $(0.03 \mathrm{~mol})$ dissolved in dry benzene $(12.0 \mathrm{ml})$ was gradually added to the ice cooled solution of compound $1(0.03 \mathrm{~mol})$ dissolved in dry benzene $(30 \mathrm{ml})$. The reaction mixture was refluxed for 3 hours. Benzene was stripped off by distillation and the residue was washed first with aq. sodium bicarbonate solution (5\%) to remove unreacted chloroacetyl chloride and then with water. The product was dried and recrystallized from ethanol as light-yellow crystals. Yield: $73.27 \%$; m.p: $156^{\circ} \mathrm{C}$; $\mathrm{IR}(\mathrm{KBr})\left(\mathrm{cm}^{-1}\right): 731,838,1542,1568,1679,3082$, 3100, 3358; ${ }^{1} \mathrm{H}-\mathrm{NMR}\left(300 \mathrm{MHz}, \mathrm{DMSO}_{\mathrm{d}}\right.$ ): $\delta$ (in $\mathrm{ppm})=2.51(\mathrm{DMSO}), 4.12\left(\mathrm{~m},-\mathrm{CH}_{2}\right), 6.91(\mathrm{~s}$, $1 \mathrm{H}$, thiazole), 7.39(m, Ar-H), $7.87(\mathrm{~m}, \mathrm{Ar}-\mathrm{H}), 9.37$ (s, NHCO). Anal. Calc. for $\mathrm{C}_{11} \mathrm{H}_{9} \mathrm{~N}_{2} \mathrm{OCIS}$ : C 52.28, $\mathrm{H}$ 3.59, N 11.08; Found: C 52.22, H 3.60, N 11.05.

Synthesis of N-(4-bromo-2-fluorophenyl)3-oxo-3-(2-(2-oxo-2-((4-phenylthiazol-2-yl)amino) 
ethyl)hydrazinyl)propanamide (4): A solution of compound $2(0.001 \mathrm{~mol})$ in absolute ethanol $(15$ $\mathrm{ml}$ ), 4-Bromo-2-fluoro phenyl malonamic hydrazide (3) (synthesized according to our reported method ${ }^{34}$ ) $(0.001 \mathrm{~mol})$ in ethanol $(10 \mathrm{ml})$ were mixed in a round bottom flask having condenser carrying a calcium chloride guard tube, DMF (1 drop) and Pyridine (1 drop) were added and the mixture was refluxed for 10 hours. Most of the ethanol was distilled off, solid was collected under suction, washed successively with water and several time with hot ethanol. The product was obtained as white crystals. Yield: 50.36\%; m.p: $196^{\circ} \mathrm{C}$; I.R. $\left(\mathrm{KBr}, \mathrm{cm}^{-1}\right)$ 610, 1038, 1115, 1427, 1536, 1664, 2884, 3049, 3285; ' ${ }^{H}$-NMR $\left(300 \mathrm{MHz}, \mathrm{DMSO}_{\mathrm{d} 6}\right): \delta$ (in ppm) $=2.50$ (DMSO), $2.89\left(\mathrm{~s}, \mathrm{CH}_{2}\right), 3.03(\mathrm{~s}, \mathrm{NH}), 3.25(\mathrm{~s}, \mathrm{NH}), 3.34$ (s, $\left.\mathrm{CH}_{2}\right), 4.24(\mathrm{~s}, \mathrm{NH}), 6.62(\mathrm{~s},-\mathrm{C} 5 \mathrm{H}$ thiazole ring), 7.21-7.48 (m, Ar-H), 9.04 (s, CONH). Anal. Calc. for $\mathrm{C}_{20} \mathrm{H}_{17} \mathrm{~N}_{5} \mathrm{O}_{3}$ BrFS: C 47.44, H 3.38, N 13.83; Found: C 47.48, H 3.31, N 13.90.

Synthesis of 5-Chloro-6-fluoro-benzothiazol2-amine (5): To a pre-cooled glacial acetic acid $(40 \mathrm{ml}), 0.416$ mole of potassium thiocyanate and 0.05 mole of 3-chloro-4-fluoro aniline was added. The mixture was placed in freezing mixture of ice and salt and mechanically stirred while $6 \mathrm{ml}$ of bromine in $24 \mathrm{ml}$ of glacial acid was added from a dropping funnel maintaining the temperature $0^{\circ} \mathrm{C}$. After all the bromine has been added (105 min.), the solution was stirred for an additional 2 hours at $0^{\circ} \mathrm{C}$ and at room temperature for 10 hours. It was allowed to stand overnight during which an orange precipitate settled at the bottom, water $(30 \mathrm{ml})$ was added quickly and slurry was heated at $85^{\circ} \mathrm{C}$ on a steam bath and filtered hot. The orange residue was placed in a reaction flask and treated with $10 \mathrm{ml}$ of glacial acetic acid, heated again to $85^{\circ} \mathrm{C}$ and filtered hot. The combined filtrate was cooled and neutralized with concentrated ammonia solution to $\mathrm{pH} 6$ when a dark yellow precipitate was collected. Recrystallisation from ethanol and water mixture. The product was obtained as pale-yellow crystals. Yield: $89.31 \%$; m.p: $168^{\circ} \mathrm{C}$; I.R. $\left(\mathrm{KBr}, \mathrm{cm}^{-1}\right)$ $691,791,1385,1638,2920,3058,3249,3433 ;{ }^{1} \mathrm{H}-$ $\operatorname{NMR}\left(300 \mathrm{MHz}, \mathrm{DMSO}_{-\mathrm{d} 6}\right): \delta$ (in ppm) $=2.51$ (DMSO), $4.82\left(\mathrm{~s},-\mathrm{NH}_{2}\right), 7.88(\mathrm{~d}, \mathrm{Ar}-\mathrm{H}), 8.20(\mathrm{~d}, \mathrm{Ar}-\mathrm{H})$. Anal.
Calc. for $\mathrm{C}_{7} \mathrm{H}_{4} \mathrm{~N}_{2} \mathrm{ClFS}$ : C 41.49, $\mathrm{H} 1.99, \mathrm{~N} 13.82$; Found: C 41.48, H 1.93, N 13.87.

Synthesis of 2-Chloro-N-(5-chloro-6fluorobenzothiazol-2yl)acetamide (6): Chloroacetyl chloride $(0.03 \mathrm{~mol})$ dissolved in dry benzene $(12.0 \mathrm{ml})$ was gradually added to the ice cooled solution of compound $4(0.03 \mathrm{~mol})$ dissolved in dry benzene $(30 \mathrm{ml})$. The reaction mixture was refluxed for 3 hours on a water bath. Benzene was stripped off by distillation and the residue was washed first with aq. sodium bicarbonate solution (5\%) to remove reacted chloroacetyl chloride and then with water. The product was dried and recrystallised from ethanol in pale yellow precipitate was obtained. Yield: $83.31 \%$; m.p: $189^{\circ} \mathrm{C}$; I.R. $\left(\mathrm{KBr}, \mathrm{cm}^{-1}\right) 693,725,760,785,1647$, 1725, 2880, 3315, 3430, 3452; ' ${ }^{\mathrm{H}-N M R}(300 \mathrm{MHz}$, DMSO- $_{\text {d6 }}$ ): $\delta$ (in ppm) $=2.51$ (DMSO), $4.58\left(\mathrm{~s},-\mathrm{CH}_{2}\right)$, 7.78 (d, Ar-H), 8.25 (d, Ar-H), 9.05 (s, -NH). Anal. Calc. for $\mathrm{C}_{9} \mathrm{H}_{5} \mathrm{~N}_{2} \mathrm{OCl}_{2} \mathrm{FS}$ : C 38.73, $\mathrm{H} 1.81, \mathrm{~N} 10.04$; Found: C 38.81, H 1.75, N 10.10.

Synthesis of 3-(2-(2-)((5-Chloro-6-fluoro -benzothiazol-2-yl)amino)-2-oxo-ethyl)hydrazinyl)$\mathrm{N}$-(4-fluoro-3-nitrophenyl)-3-oxopropanamide (8): A solution of compound $5(0.00 \mathrm{ml})$ in ethanol $(15 \mathrm{ml})$ and 3-nitro-4-fluoro malonamic acid hydrazide (7) (synthesized according to our reported method ${ }^{35}$ ) $(0.01 \mathrm{ml})$ in ethanol $(10 \mathrm{ml})$ were mixed in round bottom flask having condenser covering a calcium chloride guard tube, DMF and pyridine were added and mixture was refluxed for 10 hours. The product was separated, filtered and recrystallized from ethanol to give light brown precipitate. Yield: $72.56 \%$; m.p: $193^{\circ} \mathrm{C}$; I.R. $\left(\mathrm{KBr}, \mathrm{cm}^{-1}\right) 785,1044,1389,1545,1640$, 1668, 1710, 2930, 3055; ' ${ }^{H}$-NMR (300 MHz, DMSOd6): $\delta$ (in ppm) $=2.50$ (DMSO), $3.20\left(\mathrm{~s},-\mathrm{CH}_{2}\right), 3.55$ (s, $\mathrm{CH}_{2}$ ), 4.35 (d, NH), 7.20-7.61 (m, Ar-H), 7.48-8.72 (m, Ar-H), 9.10 (s, CONH), 9.97 (s, CONH), 12.59 (s, NH). Anal. Calc. for $\mathrm{C}_{18} \mathrm{H}_{13} \mathrm{~N}_{6} \mathrm{O}_{5} \mathrm{~F}_{2} \mathrm{ClS}$ : C 43.34, $\mathrm{H}$ 2.63, N 16.85; Found: C 43.48, H 2.61, N 16.80.

\section{Molecular and Drug likeness predictive studies} Chemdraw software was used for sketching the structures. Molecular properties, Lipinski's rule of 5 (RO5) and drug likeness score were predicted using the software from Molsoft server (http://www. 
molsoft.com) were we can draw or import the ligand file from chemdraw.

\section{RESULT AND DISCUSSION}

The research undertaken was carried out with the intention to synthesize and characterize substituted 1,3-thiazole and benzothiazole along with predicting their physico-chemical properties and drug likeness scores.

Substituted 1,3-thiazole and benzothiazoles

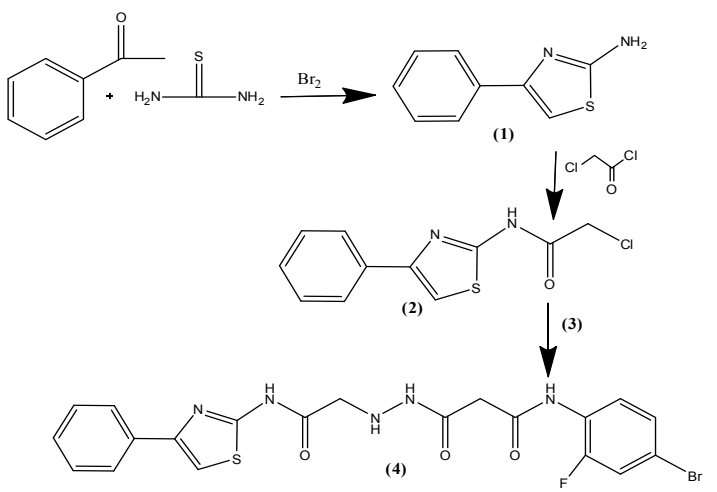

Scheme 1. Synthesis of compounds 1-4

Prediction of Lipinski's "Rule of Five" (RO5), calculation of some important physicochemical properties such as molecular weight, $\log P, \log S$, polar surface area (PSA), number of hydrogen bond acceptors (HBA), number of hydrogen bond donors (HBD), and drug likeness scores was done employing Molsoft and documented in Table 1. The
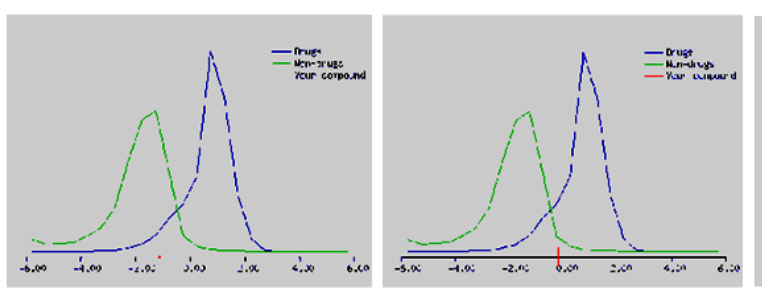

1

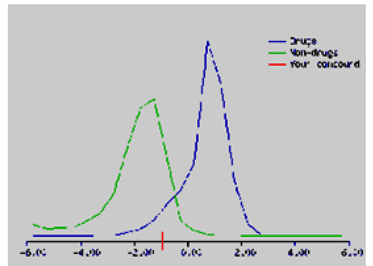

5
2

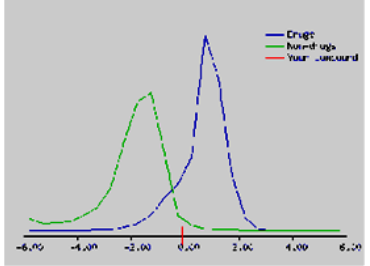

6
(1 and 5) were synthesized from acetophenone and substituted anilines respectively under different reaction conditions with different reagents. These were then allowed to react with chloroacetyl chloride under same reaction conditions to yield their respective acetamides ( 2 and 6 ). The transformation of these acetamides into their respective propenamide ( 4 and 8 ) was also achieved by reacting it with different malonamic acid hydrazides ( 3 and 7 ). Compounds 1-4 were synthesized according to scheme 1 and compounds 5-8 according to scheme 2 .

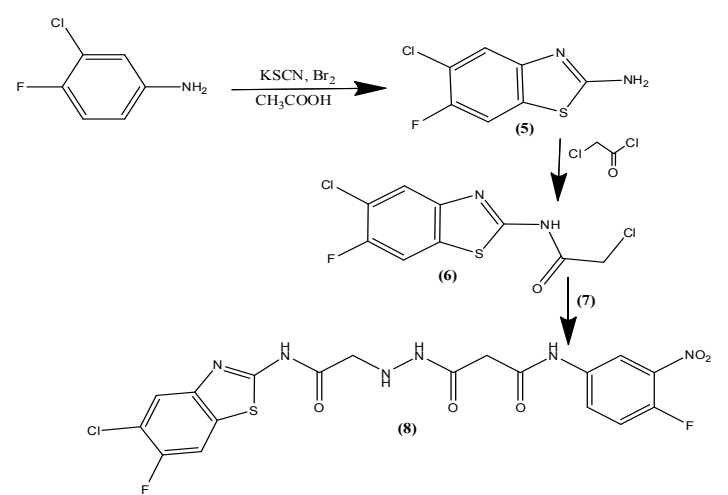

Scheme 2. Synthesis of compounds 5-8

drug likeness of the selected compounds is shown in Fig. 1. Compound 1 has violated one rule from the RO5 as it has molecular weight $>500$ but at the same time it has shown good drug likeness score of 0.18 . Rest of all the compound didn't violated the $\mathrm{RO} 5$ and their drug likeness scores ranging from -1.13 to -0.08 .
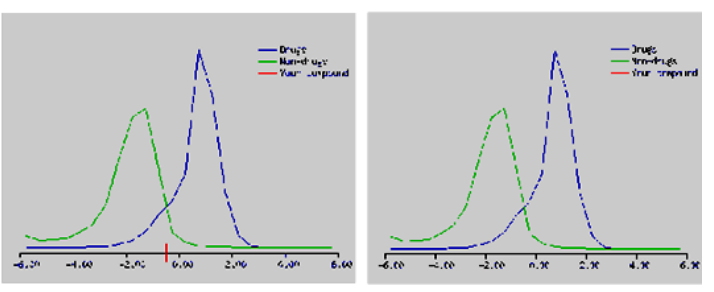

3

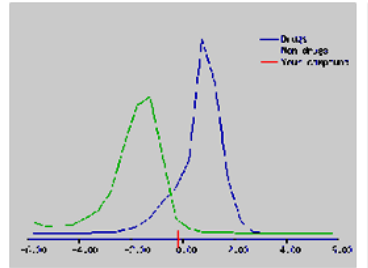

7
4

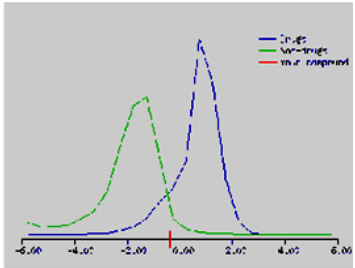

8

Fig. 1. Drug likeness scores of compounds 1-8 
Table 1: Lipinski's rule of five with additional parameters and drug likeness scores

\begin{tabular}{lccccccc}
\hline Compound No. & Mol. wt. & Log $\mathrm{P}^{\mathrm{a}}$ & Log S $^{\mathrm{b}}$ & PSA $^{\mathrm{c}}$ & HBA $^{\mathrm{d}}$ & HBD $^{\mathrm{e}}$ & Drug likeness score $^{-}$ \\
\hline 1 & 176.04 & 2.74 & -3.64 & 30.77 & 2 & 2 & -1.13 \\
2 & 252.01 & 2.94 & -4.59 & 33.16 & 3 & 1 & -0.18 \\
3 & 288.99 & 0.24 & -2.63 & 71.38 & 3 & 4 & -0.49 \\
4 & 505.02 & 2.69 & -6.50 & 94.08 & 6 & 4 & 0.18 \\
5 & 201.98 & 3.14 & -3.83 & 30.76 & 2 & 2 & -0.95 \\
6 & 277.95 & 3.33 & -4.71 & 33.15 & 3 & 1 & -0.08 \\
7 & 245.04 & 0.10 & -2.61 & 72.08 & 3 & 4 & -0.17 \\
8 & 498.03 & 1.91 & -6.10 & 127.84 & 8 & 4 & -0.36 \\
\hline
\end{tabular}

aSolubility parameter, ${ }^{\mathrm{b} C a l c u l a t e d}$ lipophilicity [in $\left.\log (\mathrm{moles} / \mathrm{L})\right]$, ${ }^{\mathrm{C}}$ Polar surface area $\left(\mathrm{A}^{2}\right)$, d Number of hydrogen bond acceptor, eNumber of hydrogen bond donors

\section{CONCLUSION}

This study encompassed on the synthesis of substituted 1,3-thiazole and benzothiazole derivatives which were characterized using spectral and elemental techniques. Compounds 1-8 were successfully synthesized and characterized. Drug likeness predictive study was undertaken to establish the RO5 and some of their physicochemical properties. Substituted 1,3-thiazole (4) violated one rule out of "rule of five", still it emerged as the most potent drug candidate in predictive studies with drug likeness score of 0.18 .

\section{ACKNOWLEDGEMENT}

Author is thankful to the Director CDRI, Lucknow for providing elemental and spectral data.

\section{REFERENCES}

1. Al-Mulla, A. Der. Pharma. Chemica., 2017, 9, 10. Hamad, N.S.; Al-Haidery, N.H.; Al-Masoudi, 141-147.

2. Valverde, M.G.; Torroba, T. Molecules., 2005, 10, 318-320.

3. Yavari. I.; Hossaini, Z. Monatsh Chem Chem Mon., 2010, 141, 229-232.

4. Chitra, C.; Sudarsan, S.; Sakthivel, S.; Guhanathan, S. Int. J. Biol. Macromol., 2017, 95, 363-375.

5. Sauer, A.C.; Leal, J.G.; Stefanello, S.T.; Leite, M.T.B.; Souza, M.B.; Soares, F.A.A.; Rodrigues, O.E.D.; Dornelles, L. Tett. Lett., 2017, 58, 87-91.

6. Husain, A.; Rashid, M.; Shaharyar, M.; Siddiqui, A.A.; Mishra, R. Eur. J. Med. Chem. 2013, 62, 785-798.

7. Ngoc, T.D.; Moons, N.; Kim, Y.; Borggraeve, W.D.; Mashentseva, A.; Andrei, G.; Snoeck, R.; Balzarini, J.; Dehaen, W. Bioorg. Med. Chem., 2014, 22, 3292-3300.

8. Çavus, M.S.; Gür, M.; Nesrin, S. J. Mol. Str., 2017, 1139, 111-118.

9. Oruc, E.E.; Rollas, S.; Kandemirli, F.; Shvets, N.; Dimoglo, A. S. J Med Chem., 2004, 47, 6760-6767. I.A.; Sabri, M.; Sabri, L.; Al-Masoudi, N.A.; Arch Pharm Chem Life Sci., 2010, 343, 397-403.

11. Siddiqui, N.; Arshad, M.F.; Ahsan, W.; Aslam M.S. Int. J. Pharm. Sci. Drug Res., 2009, 1, 136-143.

12. Guay, D.R.P. Clin. Ther., 2002, 24, 473-489.

13. Kempf, D.J.; Marsh, K.C.; Denissen, J.F.; McDonald, E.; Vasavanonda, S.; Flentge, C.A.; Green, B.E.; Fino, L.; Park, C.H.; Kong, X.P. Proc. Natl. Acad. Sci. U.S.A., 1995, 92, 2484-2488.

14. Patt, W.C.; Hamilton, H.W.; Taylor, M.D.; Ryan, M.J.; Taylor, D.G.; Connolly, C.J.; Doherty, A.M.; Klutchko, S.R.; Sircar I.; Steinbaugh, B.A. J. Med. Chem., 1992, 35, 2562-2572.

15. Hargrave, K.D.; Hess, F.K.; Oliver, J.T. J. Med. Chem., 1983, 26, 1158-1163.

16. Ergenc, N.; Capan, G.; Gunay,N.S.; Ozkirimli, S.; Gungor, M.; Ozbey, S.; Kendi, E. Arch. Pharm. Pharm. Med. Chem., 1999, 332, 343-347.

17. Carter, J.S.; Kramer, S.; Talley, J.J.; Penning, T.; Collins, P.; Graneto, M.J.; Seibert, K.; Koboldt, C.M.; Masferrer, J.; Zweifel, B. Bioorg. Med. Chem. Lett., 1999, 9, 1171-1174. 
18. Sharma, R.N.; Xavier, F.P.; Vasu, K.K.; Chaturvedi, S.C.; Pancholi, S.S. J. Enzyme Inhib. Med. Chem., 2009, 24, 890-897.

19. Badorc, A.;Bordes, M.F.; Cointet, P.; Savi, P.; Bernat, A.; Lalé, A.; Petitou, M.; Maffrand, J. P.; Herbert, J. M. J. Med. Chem., 1997, 40, 3393-3401.

20. Shao, L.; Zhou, X.; Hu, Y.; Jin, Z.; Liu, J.; Fang, J.X. Synthesis and Reactivity in Inorganic, Metal-Organic, and Nano-Metal Chemistry., 2006, 36, 25-330.

21. Kouatly, O.; Geronikaki, A.; Kamoutsis, C.; Litina, D.H.; E; eftheriou, P. Eur. J. Med. Chem., 2009, 44, 1198-1204.

22. Shibamoto, T. J. Agric. Food Chem., 1980, 28, 237-243.

23. Reddy, P.; Lin, Y.; Chang, H. Arcivoc., 2007, 16, 113-122.

24. Schneider, C.; Griss, G.; Hurnaus, R.; Kobinger, W.; Pichler, L.; Bauer, R.; Mierau, J.; Hinzen, D.; Schingnitz, G. Eur. Patent., 1986, 1, 860, 87B1.

25. Murthi, Y.; Pathak, D. J Pharm Res., 2008, 7, 153-155.

26. Florence, D.; Avellaneda, A.; Giorgio, C.D.; Robin, M.; Clercq, E.D.; David, P.T.; Galy, J.P.
Eur. J. Med. Chem., 2004, 39, 685-690.

27. Amit, B.N.; Kamath, R.V.; Khadse, G.B. Ind. J. Heterocycl. Chem., 2000, 9, 309-310.

28. Nagarajan, S.R.; De, C.G.A.; Getman, D.P.; Lu, H.F.; Sikorski, J.A.; Walker, J.L.; Donald, J. J.; Houseman, K.A.; Kocan, G.P.; Kishore, N.; Methta, P.P.; Funkes-Shippy, C.L.; Blystone, L., J Bioorg. Med. Chem., 2003, 11, 4769-4777.

29. Oketani, K.; Nagakura, N.; Harada, K.; Inoue, T. Eur. J. Pharm., 2001, 422, 209-216.

30. Saeed, S.; Rashid, N.; Jones, P.G.; Ali, M.; Hussain, R. Eur. J. Med. Chem., 2010, 45, 1323-1331.

31. Kumar, P.; Shrivastava, B.; Pandeya, S.N.; Tripathi, L.; Stables, J. P. Med. Chem. Res., 2012, 21, 2428-2442.

32. Lipinski, C.A. J. Pharmacol Toxicol Methods., 2000, 44, 235-239.

33. Lipinski, C.A.; Lombardo, F.; Dominy, B.W.; Feeney, P. J. Adv. Drug Deliv. Rev., 2001, 46, 3-2.

34. Shahnawaz, M.; Naqvi, A. Res. J Pharm. Bio. Chem., 2012, 3, 49-52.

35. Naqvi, A.; Malasoni, R.; Srivastava, A.; Pandey, R.R.; Dwivedi, A.K. Bioorg. Med. Chem. Lett., 2014, 24, 5181-5184. 